\title{
The Impact of Country of Origin and Country of Manufacture of a Brand on Overall Brand Equity
}

\author{
Rasha H. A. Mostafa ${ }^{1}$ \\ ${ }^{1}$ Faculty of Commerce, Ain-Shams University, Cairo, Egypt \\ Correspondence: Rasha Hussein Abdel Aziz Mostafa, Faculty of Commerce, Ain-Shams University, El-Kalifa El \\ Mamoon St., Abbasia, 11566, Cairo, Egypt. Tel: 2-0100-102-8242. E-mail: rashamostafa98@gmail.com
}

Received: February 21, 2015

Accepted: March 7, 2015 Online Published: March 28, 2015

doi:10.5539/ijms.v7n2p70

URL: http://dx.doi.org/10.5539/ijms.v7n2p70

\begin{abstract}
The main purpose of this study is to explore the effects of country-of-origin of a brand (COB) and country of manufacture $(\mathrm{COM})$ on the overall brand equity $(\mathrm{OBE})$. A second purpose of this research is to investigate the mediating role of consumer based brand equity (CBBE) on the relationship between $\mathrm{COB}$ and $\mathrm{COM}$ and overall brand equity (OBE). To undertake this, a conceptual framework was designed and relationships among its constructs $\mathrm{COB}, \mathrm{COM}, \mathrm{CBBE}$, and OBE were hypothesized. Data were collected from consumers located in two major cities in Egypt who were the owners of the selected brands of mobile phones. All hypotheses were tested using regression analysis. Results indicate that both $\mathrm{COB}$ and $\mathrm{COM}$ have direct and significant effect on $\mathrm{CBBE}$, yet COM has significant lower effect on CBBE. In addition, $\mathrm{COB}$ and COM have direct influence on the overall brand equity. Furthermore, unlike $\mathrm{COB}$, the results emphasized the mediating effect of $\mathrm{CBBE}$ on the relationships between $\mathrm{COM}$ and the overall brand equity. The current study considers only one product category, future researches would consider different product categories, for example convenience products and non-durable ones. Further research would take into account $\mathrm{COB}$ and COM effects from other developed and developing countries. Different sub-dimensions of $\mathrm{COO}$ for example Country of Assembly (COA) and Country of Design (COD) would be researched. The value of this paper stems from decomposing country of origin into $\mathrm{COB}$ and $\mathrm{COM}$ and investigating their plausible effect on the CBBE and the overall brand equity from the Egyptian consumers' points of view. Moreover, the mediating effect of CBBE is another significant issue.
\end{abstract}

Keywords: country of origin of brand, country of manufacture, consumer based brand equity, brand equity, Egypt

\section{Introduction}

Since its emergence in the 1960 s, branding has attracted the attention of many researchers, with special emphasis on Brand Equity (BE) (Zeugner-Roth et al., 2008; Swaminathan et al., 2009; Keller, 2010; Hamzaoui-Essoussi et al., 2011). According to Keller (2013), brand equity represents the value that consumers associate with a brand. Hence, it reflects consumers' perceptions towards a particular brand (Yasin et al., 2007). Furthermore, branding plays an integral role in acquiring and maintaining long term competitive advantage (Ha et al, 2010; Chang \& Liu, 2009; Boo et al., 2009; Moradi \& Zarei, 2012; Ishaq et al., 2014).

Despite the importance of brand equity, most researches concentrated on developing brand equity measurement constructs with little emphasis on factors influencing it (Valette-Florence et al., 2011). Moreover, globalization and increased international trade made products from one country available to consumers in another country. Therefore, the country of origin (COO) or the 'made in' label of a product creates secondary association (Baldauf et al., 2009). Country of origin (COO) shapes consumers perceptions, manipulates their preferences and choices of a particular brand, and their tendencies to pay more. In a developing country like Egypt, consumers perceive country of origin of a product as a manifestation of its overall quality, besides sometimes COO symbolizes status and enhance consumer's self-esteem.

However, despite the increased manifestation of multi-national organizations that encourage the emergence of bi-national products where country of origin could be decomposed into its fundamental elements (e.g., country of brand (COB), country of manufacture (COM), country of assembly (COA), and country of design (COD)), brands are still undoubtedly the organization's ultimate asset in today's competing world (Khan and Mahmood, 
2012). In an international environment, researchers reported the influential effect of $\mathrm{COO}$ on brand equity dimensions (Pappu et al., 2006, 2007; Yasin et al., 2007; Baldauf et al., 2009).

This research is intended to add to the extant literature as follows: first, most of brand equity researches have focused on either Americans or Asian markets, with very little attention is given to developing countries. The importance of studying consumers from developing countries stems from the significance of $\mathrm{COO}$ image to consumers in those countries. Batra et al. (2000) emphasized the reasons for such strength as follows: consumers in developing countries, who afford buying imported products at a high price, symbolize high economic and social status, which represent wealth; further imitating western lifestyle and purchasing luxury products originated in more developed countries elevate consumers' self-esteem and indicate modernity. Therefore, the current study focuses on the Egyptian market, as an example of a developing country. Second, most of the studies conducted in the area targeted student samples (e.g., Yoo \& Donthu, 2001, 2002; Broyles et al., 2010). Yet, the present study uses data from various Egyptian consumers. Finally, most of the studies treated COO as a single extrinsic cue shaping consumers' perceptions while evaluating products 'made in' a particular country, with few studies that examined $\mathrm{COO}$ elements. Hence, the present study decomposes $\mathrm{COO}$ into Country of Origin of Brand (COB) and Country of Manufacture (COM) as a further step in this direction. Given the above, the purpose of the study is to explore the effects of sub-component of COO namely, Country of Brand (COB) and Country of Manufacture (COM) on brand equity formation.

In the following sections, an overview of the relevant literature on brand equity and country of origin effects on the consumer based brand equity concept is presented, from which the conceptual framework and research hypotheses are postulated. Next, the methodology used to guide this research is briefly reviewed. Thereafter, discussion of the results is outlined. Finally, conclusions, limitations and suggestions for future research are presented.

\section{Literature Review and Hypotheses Development}

\subsection{Brand Equity and Its Dimensions}

Since its emergence in the 1980's, brand equity has become a core concept and a key field of research in marketing (Ambler, 2003; Samli \& Fevrier, 2008; Buil et al., 2013). It has been even intensified due to globalization and increased competition (Pinar et al., 2014). Several attempts have been proposed to define and conceptualize the term from the financial perspective, the consumer-based perspective, or the holistic perspective (Aaker, 1991; Srinivasan et al., 2005; Keller, 1993, 2008). It should be noted that the financial value of a brand is fundamentally based on how the consumers are responding and reacting to the brand (Christodoulides \& de Chernatony, 2010). Further, if a brand has no value for the customer, it means that its financial value is nil, implying that it does not really exist in the market place (Keller, 1993; Pappu et al., 2005). Consequently, the vast majority of studies tackled brand equity concept form the consumer point of view.

Aaker $(1991,1996)$ and Keller (1993) introduced to the brand equity domain the consumer-based perspective concept. Aaker (1991, p. 15) defines brand equity as "a set of assets and liabilities linked to a brand, its name and symbol that add to or subtract from the value provided by a product or service to a firm and/or to that firm customers". Aaker (1996) further categorized the assets and liabilities into "brand awareness, perceived brand quality, brand image/associations, and brand loyalty" (p. 103), where the first three elements are perceptual in nature, brand loyalty is considered a behavioral one.

However, Keller (1993) perceived consumer-based brand equity (CBBE) as "the differential effect of brand knowledge on consumer response to the marketing of the brand" (p. 2). According to Keller (2013, p. 45) brand knowledge comprises awareness, attributes, benefits, images, thoughts, feelings, attitudes and experience. Additionally, Keller (2008, p. 48) underscored that "CBBE occurs when the consumer has a high level of awareness and familiarity with the brand and holds some strong, favorable, and unique brand associations in memory".

Recently, Christodoulides and de Chernatony (2010) have defined CBBE as "a set of perceptions, attitudes, knowledge, and behaviours on the part of consumers that results in increased utility and allows a brand to earn greater volume or greater margins than it could without the brand name" (p. 48). This definition is perceived as a combination of both Aaker (1991) and Keller (1993) consumer-based brand equity definitions.

Hence, this study follows Aaker's (1991) consumer-based brand equity definition, which has been broadly accepted and commonly employed and cited by many researchers (e.g., Yoo et al., 2000; Kim et al., 2003; Pappu et al., 2005; Chen and Tseng, 2010; Smutkupt et al., 2012; Buil et al., 2013). Accordingly, consumer-based 
brand equity dimensions consist of brand awareness, perceived quality, brand associations, and brand loyalty (Aaker, 1991, 1996).

Brand awareness is defined as "the ability of the potential buyer to recognize and recall that a brand is a member of a certain product category (Aaker, 1991). Whereas, Keller (1993, p. 3) stated that brand awareness is "related to the likelihood that a brand name will come to mind and the ease with which it does so". Keller $(1993,2008)$ stressed that without being aware of, and familiar with the brand, building strong and favorable brand image will not be possible. Perceived quality is a key dimension of brand equity. Aaker (1991) and Keller (2003) defined it as "the customer's perception of the overall quality or superiority of a product or service with respect to its intended purpose, relative to alternatives". Brand associations and brand image have been used interchangeably in the literature. According to Aaker (1991), brand image is "anything linked in memory to a brand, usually in some meaningful way" (p. 109). Finally, brand loyalty as a behavioural dimension is "a measure of the attachment a customer has to a brand" (Aaker, 1991, p. 39), which in turn results in frequent purchases of the brand (Khan and Mahmood, 2012). Yet from an attitudinal perspective, Yoo and Donthu (2001, p. 3) described it as "the tendency to be loyal to a focal brand, which is demonstrated by the intention to buy the brand as a primary choice".

Many studies revealed associations between consumer-based brand equity dimensions and brand equity in different contexts and diverse cultures. Yoo and Donthu (2002) tested brand equity model in a cross-cultural context, namely Korea and USA. The results revealed that brand loyalty was the most important determinant of brand equity in both countries under investigation, yet with different level of effect. Further, the influence of perceived quality on brand equity was greater in the Korean sample relative to the USA one. Finally, the study found an equivalent positive effect of brand awareness on brand equity in both countries. Likewise, Chen and Tseng (2010), Khan and Mahmoud (2012), Buil et al. (2013) and Murtiasih et al. (2014) reported a significant positive relationship between brand loyalty and brand equity, emphasizing that brand loyalty is a key construct and main determinant explaining brand equity. Moreover, Tong and Hawley (2009) studied the Chinese sportswear market. The findings revealed that brand association and brand loyalty are influential dimensions of brand equity. Weak support was found for the perceived quality and brand awareness dimensions. Further, Chen et al. (2012) reported significant positive association between brand image and brand equity among Taiwanese students. Similarly, Buil et al. (2013) underscored significant positive effect of brand image and perceived quality on overall brand equity. Consistently, Mourad et al. (2011) reported that brand image has far more significant effect on brand equity compared to brand awareness in the higher education sector. Yet, Pinar et al. (2014) asserted that perceived quality of faculty is the most important brand equity dimension for creating strong university brand, followed by university reputation and emotional environment, brand loyalty, and brand awareness dimensions.

\subsection{Country of Origin (COO)}

Country of origin (COO) of a product is considered, and extensively researched, as one of the extrinsic cues, which affects consumer perceptions, preferences, purchase intention, choices and overall product evaluation (Bilkey \& Nes, 1982; Han \& Terpstra, 1988; Peterson \& Jolibert, 1995; Apil, 2006; Apil, 2006; Yasin et al., 2007, Lee \& Lee, 2011; Shain et al., 2013). For so many years COO has been defined as "the country of manufacture or assembly" (Prendergast et al., 2010; Bamber et al., 2011; Rackchamroon \& Chaimanat, 2011). However, the advances of globalization gave great attention to country of origin $\mathrm{COO}$ effect as one of the factors influencing international competitiveness (Bamber et al., 2011). In addition, the growth of multinational organizations, along with the heavy foreign direct investments in less developed and developing countries, with the aim of cutting operations costs and capitalizing on lower wage rates, have accelerated the emergence of bi-national/hybrid products and brands (Haubl \& Elrod, 1999, Prendergast et al., 2010).

A bi-national/hybrid product could be designed in one country, manufactured in another, assembled in a third one, while the brand itself is originated from a fourth country (Bilkey \& Nes, 1982; Chao, 1993; Ulgado \& Lee, 1993; Prendergast et al., 2010; Fetscherin \& Toncar, 2010; Ahmed et al., 2012; Saeed et al., 2013). Highlighting the fact that $\mathrm{COO}$ can no longer be examined as a simple concept; instead it should be studied as a multi-dimensional one, specifically with the current technological advances, which allow consumers to associate various countries with a single brand (Hamzaoui-Essoussi et al., 2011; Bamber et al., 2011), and further complicate consumers perceptions of those hybrid products (Chen \& Su, 2012).

Apparently, it is getting more difficult to define COO, nevertheless to conceptualize it. Therefore, some researchers questioned previous studies results on the effect of $\mathrm{COO}$ on product evaluation due to the reliance on COO as a single cue (Chao et al., 2005; Prendergast et al., 2010), and the failure of recognizing the difference 
and the importance of both country of brand origin (COB) and country of manufacture (COM) as elements of COO (Iyer and Kalita, 1997).

It is worth noting that in case of lacking other products attributes, $\mathrm{COO}$ or the 'made in' label is used to evaluate different products/brands and influence their equity either positively or negatively depending upon country stereotype (Ulgado \& Lee, 1993). This reflects the positive or negative perceptions the consumers hold towards the 'made in' country (Apil, 2006, Pappu et al., 2007; Yasin et al., 2007; Ahmed et al., 2012). Liu (2012) studied China stereotype effect and concluded that its negative effect is transferrable to all other product categories that hold the 'made in China' label. Further, Haubl and Elord, (1999) and Hui and Zhou (2003) reported that strong brands are highly affected and negatively evaluated when manufactured at a less favorable country than their country of brand (COB), while the same is applicable to COB (Fetscherin \& Toncar, 2010). Generally speaking, brands associated with countries with positive stereotypes will benefit from it and vice versa (Johansson \& Nebenzahl, 1986; Chen \& Su, 2012). However, in the presence of familiar brand name and specific product attributes, COM effects were significantly diminished, and consumers based their product overall evaluation on its brand name (Ulgado \& Lee, 1993).

Ulgado and Lee (1993) and Prendergast et al. (2010) underscored the significant impact of COB on consumers purchase intention. Meanwhile, Ahmed and d'Astous (1995) and Saeed et al., (2013) emphasized the importance of COM to consumers as opposed to other $\mathrm{COO}$ sub-components (e.g., COB, COA, COD). Whereas, Chao (1993) reported that both COB and COM are equally important to consumers.

\subsubsection{The Relationship between COO and Brand Equity Dimensions}

Although researchers criticized the results of the studies exploring $\mathrm{COO}$ as a single cue, little research has been conducted that measured the relationship between the decomposition elements of $\mathrm{COO}$ (e.g., COB, COM, COA, COD) and brand equity dimensions as emphasized hereafter.

The congruity principle elucidated by Osgood and Tannenbaum (1955) postulates that, "because incongruent information creates dissonance, congruent information is preferred" (cf. Chao, 2001, p.69). Accordingly, Pappu et al. (2006) reported that Consumer-Based Brand Equity (CBBE) was significantly lower when COB was incongruent with COM. Moreover, Chao (2001) found that consumers negatively perceive products assembled, manufactured, and designed in incongruent countries. Therefore, it is highly likely that consumers will respond positively to congruent conditions as opposed to incongruent ones (Chao, 2001). Meaning that when COB and $\mathrm{COM}$ of a product/brand are consistent, consumers will reveal positive attitudes toward a foreign brand, the product/brand quality evaluation process will become easier and will increase its attractiveness (Leclerc et al., 1994; Haubl \& Elrod, 1999).

Pappu et al. (2007) studied the relationship between CBBE and country macro and micro images. The results revealed that perceived quality made the strongest contribution to the relationship examined as opposed to the rest of CBBE dimensions. Yet, it should be noted that the result was product specific (i.e., cars). Further, Shahin et al. (2013) reported that COO, defined as home country, has the greatest impact on perceived quality of household audiovisual appliances (i.e., LCD, LED and DVD). This result is in consonance with Han and Terpstra (1988) who stressed those country stimuli have more powerful effects than brand name on consumer perceptions of bi-national products quality.

Apparently, brand awareness contributes immensely in the consumers' decision-making process (Liu, 2012). Yasin et al. (2007) and Shahin et al. (2013) reported positive relationship between brand awareness and COO among Malaysian consumers and Iranian households respectively. It should be noted that Shahin et al. (2013) defined $\mathrm{COO}$ as home country or country of manufacture. However, Pappu et al. (2007) underscored that brand awareness has no contribution to macro and micro country image in the two product sets under study (i.e., televisions and cars).

Whereas in the same study, Pappu et al. (2007) revealed that brand image made the strongest contribution to macro and micro country image as opposed to the remaining CBBE dimensions with respect to televisions. In addition, Shahin et al. (2013) underscored direct and significant relationship between brand image and COO with respect to household audiovisual appliances. Yet, Johansson and Nebenzahl (1986) indicated that changing the product manufacturing location has a minor effect on the overall brand image.

Although Pappu et al. (2006, p. $701 \&$ 2007, p. 729) revealed that present studies seem to lack insights into the relationship between $\mathrm{COO}$ and brand loyalty. However, they underscored a strong relationship between brand loyalty and both macro and micro country images with respect to televisions as opposed to cars. Highlighting the effect of product category on the examined relationship. Again, the same authors in 2006 reported that 
respondents were found to be more loyal to a brand made in a country with strong association with product category as opposed to the same brand being manufactured in a country with weak association with the product category. Moreover, Yasin et al. (2007) established positive relationship between COO and brand loyalty among Malaysian consumers with respect to electrical appliances, where the good image of the $\mathrm{COO}$ leads to higher level of loyalty. Additionally, Shahin et al. (2013) found that COO had the greatest impact on brand loyalty as opposed to brand image and brand awareness. Finally, in the same token Murtiasih et al. (2014) emphasized that $\mathrm{COO}$ effect on brand equity was greater through brand loyalty than perceived quality in the Indonesian car market, in addition to a significant positive association between $\mathrm{COO}$ and $\mathrm{CBBE}$ dimensions.

Based on the above, it seems that the literature on the relationship between COB, COM and brand equity and its dimensions is largely fragmented and inconclusive. Due to this inconclusiveness of results and in order to further fill the gap in the literature concerning, examining $\mathrm{COO}$ as a single cue, this research explores the effects of COB, which is defined as "the country of origin of a brand", as well as, COM, which is defined as "the country where the product is manufactured" or "made in" (cf. Saeed et al., 2013) on brand equity and its dimensions using Aaker $(1991,1996)$ commonly cited model. Therefore, the following hypotheses are examined.

H1. (a) Perceived brand quality (b) Brand loyalty (c) Brand awareness and (d) Brand image have a significant relationship with overall brand equity $\mathrm{OBE}$

H2. Country-of-origin of brand COB has a significant relationship with (a) Perceived brand quality (b) Brand loyalty (c) Brand awareness and (d) Brand image

H3. Country-of-manufacture COM has a significant relationship with (a) Perceived brand quality (b) Brand loyalty (c) Brand awareness and (d) Brand image

H4. Country-of-origin of brand $\mathrm{COB}$ has a significant relationship with overall brand equity OBE

H5. Country-of-manufacture $\mathrm{COM}$ has a significant relationship with overall brand equity $\mathrm{OBE}$

H6. Country-of-origin of brand $\mathrm{COB}$ has a significant relationship with overall brand equity, through the mediating effects of (a) Perceived brand quality (b) Brand loyalty (c) Brand awareness and (d) Brand image

H7. Country of manufacture COM has a significant relationship with overall brand equity, through the mediating effects of (a) Perceived brand quality (b) Brand loyalty (c) Brand awareness and (d) Brand image

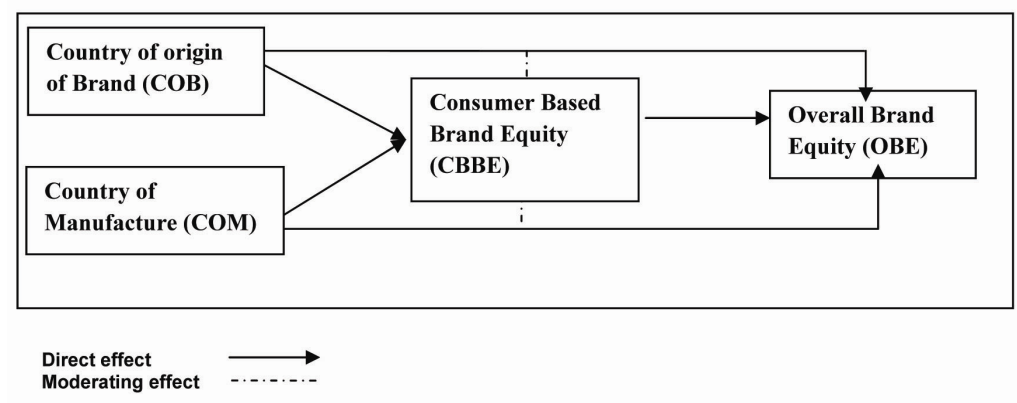

Figure 1. Research model

\section{Methodology}

\subsection{Sample Size, Data Collection and Measurements}

The product selected as stimuli for this study is mobile phone represented with three different brands namely: Blackberry, Samsung and IPhone. These particular brands were chosen due to their high relevant worldwide market share as emphasized by IDC Worldwide Mobile Phone Tracker (2013). The reason for choosing mobile phone is that it became a fact-of-life and customers are highly familiar with the brands under investigation. Therefore, it is anticipated that the respondents will provide more reliable and valid answers to the research questionnaire. Three levels of "Country of Origin of a Brand" (COB) location: Canada, South Korea and US respectively, and one level of "Country of Manufacture" (COM) location: China were specified. From the three listed brands, respondents were first asked to choose the one they were most familiar with (using it), then to respond to the rest of the questionnaire for that specific brand. 
Data were collected from 600-targeted customers who have mobile phones with brands under investigation at various locations across Cairo (the capital) and Giza. Both locations represent the biggest cities in Egypt. Respondents were asked to complete a structured questionnaire designed to collect the research primary data. A five-point Likert scale ranging from $(1=$ strongly disagree to $5=$ strongly agree $)$ was constructed to operationalize the research constructs. Further, the questionnaire was divided into five parts as follows: the first part includes some demographic and socio-economic characteristics. The second part consists of 7 items measuring country of origin of brand (COB) adopted from Yasin et al. (2007). While the third part contains 28 items measuring customer-based brand equity (CBBE) dimensions adopted from Lasar et al. (1995), Yoo et al. (2000) and Yasin et al. (2007) and classified as follows: (8 statements for brand loyalty, 9 statements for perceived quality, 4 statements for brand awareness, and 7 statements for brand image/associations). The fourth part incorporates 7 items measuring overall brand equity (OBE) adopted from Yoo et al. (2000) and consistent with Yasin et al. (2007). The Overall Brand Equity construct (OBE) helps understand how brand equity dimensions contribute to brand equity (Buil et al., 2013). Finally, the last part embraces 4 items proposed by Pisharodi and Parameswaran's (1992) and Chen and Su (2012) measuring country of manufacture (COM).

\subsection{Research Findings}

The data collected in the survey were analyzed and compared using SPSS (version 22). Descriptive statistics was used to analyze the sample's basic information. Then the reliability of the multi-dimensional constructs used was verified. Finally, the Step Wise Regression analysis was adopted to test the hypotheses.

The research findings are presented in three parts as follows: first, reliability analysis is underscored, second, sample characteristics are highlighted, and finally the results of testing the research hypotheses are underlined.

\subsubsection{Reliability Analysis}

Cronbach's alpha was applied to measure the inter-item consistency of the research constructs. The study multi-dimensional constructs Cronbach's alpha scored as follows: country of origin of brand (COB) (0.77), country of manufacture (COM) $(0.74)$, brand loyalty $(0.65)$, perceived quality $(0.81)$, brand awareness $(0.77)$, brand image (0.68), and overall brand equity (OBE) (0.78) respectively. Clearly all the research multi-dimensional constructs exceeded the suggested benchmarks for reliability (0.6) stated by Nunnally and Bernstein (1994), hence illustrating internal consistency between the items used.

\subsubsection{Sample Demographics}

The sample consisted of $422(70.3 \%)$ male and 178 (29.7\%) female respondents. In terms of age, more than half of the respondents fall in the age bracket 23 to 32 years (59\%). In terms of education level, again more than half of the respondents $368(61.3 \%)$ had a college degree while 127 had a high school degree (21\%). Finally, the sample indicates that 239 respondents $(40 \%)$ earn between 1000 and 3000 EGP/month. Sampled respondents indicated variance in all demographic characteristics such as gender, age, level of education and income level. Such discrepancies reflect the real Egyptian consumer population. Therefore allow for research findings generalization than most previous research often based on student samples (e.g. Johansson et al., 1985; Ettenson et al., 1988).

\subsubsection{Hypotheses Testing}

Stepwise Regression Analysis was employed to examine the research hypotheses. Based on the research framework, consumer-based brand equity (CBBE) dimensions (brand loyalty, perceived quality, brand awareness and brand image) conceived to influence overall brand equity (OBE). OBE was regressed on all (CBBE) dimensions, and the results are shown in Table (1).

The model is significant at $p \leq 0.01$ indicating 99 percent confidence in the independent variables namely: CBBE dimensions in explaining the dependent variable OBE. All four variables are found to have a significant and positive influence on OBE at a significant level of 0.000 . The $\mathrm{R}^{2}$ of 0.969 indicates that almost 97 percent of the variance in $\mathrm{OBE}$ was explained by the variations in perceived quality, brand loyalty, brand image and brand awareness respectively. The variables highlighted in Table (1) are in the same order of entering the model. Therefore, the beta coefficients are in descending order, highlighting that perceived quality has the highest influence on OBE followed by brand loyalty, brand image and finally brand awareness. These findings support H1. 
Table 1. The effect of Consumer-Based Brand Equity (CBBE) on Overall Brand Equity (OBE)

\begin{tabular}{llll}
\hline Independent variable/s (x) & Standardized $\boldsymbol{\beta e t a}$ & $\boldsymbol{t}$-value & Sig. $\boldsymbol{p}$ - value \\
\hline Perceived quality & 0.403 & 37.82 & $.000^{* * *}$ \\
Brand loyalty & 0.351 & 34.06 & $.000^{* * *}$ \\
Brand image & 0.271 & 24,48 & $.000^{*} * *$ \\
Brand awareness & 0.123 & 12.33 & $.000^{*} * *$ \\
\hline
\end{tabular}

Notes. $\mathrm{R}^{2}=0.969$, Adjusted $\mathrm{R}^{2}=0.969, \mathrm{~F}=4702.136, * * * p \leq 0.001$.

The results of the regression analysis testing the relationship between country of origin of brand COB and each of the dimensions of consumer based brand equity CBBE is shown in Table (2). All four models are significant at $F \leq 0.01$. The result indicates existing positive and significant relationship between country of origin of brand $\mathrm{COB}$ and each and every dimension of $\mathrm{CBBE}$. The $\mathrm{R}^{2}$ values indicated that the country of origin of brand COB contributed in explaining the variance in CBBE dimensions namely: brand loyalty, perceived quality, brand awareness and brand image by 28.9, 39, 23 and 30 percent respectively. This result fully supports $\mathrm{H} 2$.

Table 2. The effect of Country of Origin of Brand (COB) on Consumer-Based Brand Equity (CBBE)

\begin{tabular}{|c|c|c|c|c|c|}
\hline Dependent variable/s (y) & Standardized Beta & $t$-value & Sig. $p$-value & $\mathbf{R}^{2}$ & Sig. $F$ \\
\hline Brand loyalty & 0.538 & 15,603 & $.000 * * *$ & 0.289 & $.000 * * *$ \\
\hline Perceived quality & 0.628 & 19.713 & $.000 * * *$ & 0.394 & $.000 * * *$ \\
\hline Brand awareness & 0.483 & 13.492 & $.000 * * *$ & 0.233 & $.000 * * *$ \\
\hline Brand image & 0.553 & 16.222 & $.000 * * *$ & 0.306 & $.000 * * *$ \\
\hline
\end{tabular}

Note. $* * * p \leq 0.001$.

The result of the regression analysis testing the relationship between country of manufacture COM and each of consumer based brand equity CBBE dimensions is shown in Table (3). Despite the significance of all four models at $F \leq 0.01$, hence supporting H3, however, the ability of COM to explain the variances in each CBBE dimension seems to be very weak considering the $\mathrm{R}^{2}$ values highlighted hereunder.

Table 3. The effect of Country of Manufacture (COM) on Consumer-Based Brand Equity (CBBE)

\begin{tabular}{llllll}
\hline Dependent variable/s (y) & Standardized Beta & $\boldsymbol{t}$ - value & Sig. $\boldsymbol{p}$ - value & $\mathbf{R}^{\mathbf{2}}$ & Sig. $\boldsymbol{F}$ \\
\hline Brand loyalty & 0.25 & 6.325 & $.000^{* * *}$ & 0.063 & $.000^{* * *}$ \\
Perceived quality & 0.27 & 6.849 & $.000^{* * *}$ & 0.073 & $.000^{* * *}$ \\
Brand awareness & 0.24 & 6.087 & $.000^{* * *}$ & 0.058 & $.000^{* * *}$ \\
Brand image & 0.25 & 6.339 & $.000^{* * *}$ & 0.063 & $.000^{* * *}$ \\
\hline
\end{tabular}

Note. $* * p \leq 0.001$

In consensus with Baron and Kenny (1986) suggestion to test the mediating effect of consumer based brand equity $(\mathrm{CBBE})$ on country of origin of brand $(\mathrm{COB})$ and country of manufacture (COM)_overall-brand equity (OBE) linkage, the following propositions must be fulfilled:

1. Significant relationship between the independent and mediating variable;

2. Significant relationship between the independent and dependent variable; and

3. Significant relationship between the independent and dependent variable in the presence of the mediator.

To demonstrate further mediation, Baron and Kenny (1986) further suggest that the effect of the independent variable on the dependent one is reduced or even disappears in the case of full mediation.

Tables (2 and 3) fulfill Baron and Kenny's (1986) first proposition. While, the second proposition is supported by the results highlighted in Tables (4 and 5). The findings indicated significant positive association between $\mathrm{COB}$ and COM respectively as independent variables and overall brand equity OBE as the dependent one. Also, the regression models assure that both $\mathrm{COB}$ and $\mathrm{COM}$ contributed to the total variance of OBE by 42 percent and 0.08 percent respectively. Hence, research hypotheses $\mathrm{H} 4$ and $\mathrm{H} 5$ are supported. 
Table 4. The effect of Country of Origin of Brand (COB) on Overall Brand Equity (OBE)

\begin{tabular}{llll}
\hline Independent variable $(\mathbf{x})$ & Standardized $\boldsymbol{\beta e t a}$ & $\boldsymbol{t}$-value & Sig. $\boldsymbol{p}$ - value \\
\hline Country of origin of brand $(\mathrm{COB})$ & 0.651 & 20.954 & $.000^{* * *}$ \\
\hline
\end{tabular}

Notes. $\mathrm{R}^{2}=0.423$, Adjusted $\mathrm{R}^{2}=0.422, \mathrm{~F}=439.06, * * * p \leq 0.001$.

Table 5. The effect of Country of Manufacture (COM) on Overall Brand Equity (OBE)

\begin{tabular}{llll}
\hline Independent variable $(\mathbf{x})$ & Standardized Beta & $\boldsymbol{t}$-value & Sig. $\boldsymbol{p}$ - value \\
\hline Country of manufacture $(\mathrm{COM})$ & 0.292 & 7.475 & $.000^{* * *}$ \\
\hline
\end{tabular}

Notes. $\mathrm{R}^{2}=0.085$, Adjusted $\mathrm{R}^{2}=0.084, \mathrm{~F}=55.876, * * * \leq 0.001$.

Finally, to fulfill the third proposition suggested by Baron and Kenny (1986) four regression analyses were conducted to test the mediating effect of brand loyalty, perceived quality, brand awareness and brand image on country of origin of brand $\mathrm{COB}$ and country of manufacture COM and overall brand equity OBE relationship. The results are shown in Tables (6 and 7).

In Table (6) Model 1 shows the relationship between country-of-origin of brand COB and overall brand equity. whereas, Model 2 represents the mediated regression that shows the relationship between COB and overall brand equity OBE with the inclusion of the consumer based brand equity CBBE mediating variables (brand loyalty, perceived quality, brand awareness and brand image). According to Baron and Kenny (1986), for mediating effect to exist the beta coefficients in Model 2 should be less than their counterparts in Model 1.

The results show that country-of-origin of brand COB is significant in the regressions mediated by brand loyalty, perceived quality, brand awareness and brand image, with almost indifferent decrease in the beta coefficients across all consumer based brand equity dimensions except for brand loyalty. This result indicates that CBBE dimensions do not mediate country-of-origin of brand $\mathrm{COB}$-overall brand equity OBE relationship. Therefore, H6 is rejected.

Table 6. The relationship between Country of Origin of Brand COB and Overall Brand Equity OBE Mediated by Consumer Based Brand Equity CBBE Dimensions

\begin{tabular}{llll}
\hline Independent variables & Mediating variables & Model 1 & $\begin{array}{l}\text { Model 2 } \\
\text { Std. } \beta \text { Beta }\end{array}$ \\
\hline Country of origin of Brand COB & Brand loyalty $\beta$ Beta & $0.65 * * *$ & $0.65 * * *$ \\
Country of origin of Brand COB & Perceived quality & $0.65 * * *$ & $0.64 * * *$ \\
Country of origin of Brand COB & Brand awareness & $0.65 * * *$ & $0.63 * * *$ \\
Country of origin of Brand COB & Brand image & $0.65 * * *$ & $0.63 * * *$ \\
\hline
\end{tabular}

Note. $* * * p \leq 0.001$.

Contrary to the above-mentioned results, Table (7) indicates that country-of-manufacture COM is significant in the regressions mediated by brand loyalty, perceived quality, brand awareness and brand image, with a remarkable decrease in the beta coefficients of all consumer based brand equity CBBE dimensions as highlighted in Model 2 as opposed to their counterparts showed in Model 1. Such result confirms Baron and Kenny (1986) condition for mediating effect to exist. Accordingly, $\mathrm{H} 7$ is fully supported and confirming the mediating effect of consumer based brand equity CBBE dimensions on country of manufacture COM - overall brand equity OBE relationship.

Table 7. The relationship between Country of Manufacture COM and Overall Brand Equity OBE Mediated by Consumer Based Brand Equity CBBE Dimensions

\begin{tabular}{llll}
\hline Independent variables & Mediating variables & Model 1 & $\begin{array}{l}\text { Model 2 } \\
\text { Std. } \boldsymbol{\beta e t a}\end{array}$ \\
\hline Country of Manufacture COM & Brand equity dimensions & $0.292 * * *$ & $0.097 * * *$ \\
Country of Manufacture COM & Perceived quality & $0.292 * * *$ & $0.08 * * *$ \\
Country of Manufacture COM & Brand awareness & $0.292 * * *$ & $0.087 * * *$ \\
Country of Manufacture COM & Brand image & $0.292 * * *$ & $0.09 * * *$ \\
\hline
\end{tabular}

Note. $* * * p \leq 0.001$. 


\section{Conclusion}

This study examines the effect of country of origin of brand (COB) and country of manufacture (COM) on overall brand equity (OBE) of three different brands of mobile phones originated in three diverse countries. Nevertheless, all of them were manufactured in China. Results indicated that the brand equity of mobile phones consists of four dimensions namely: perceived quality, brand loyalty, brand image and brand awareness. The findings support all of Aaker's consumer-based brand equity (CBBE) dimensions, where all four dimensions were positively and significantly influencing mobile phones overall brand equity. However, among the four dimensions, perceived quality had the highest impact on brand equity, indicating the importance of quality in building mobile phones brand equity. This result is inconsistent with Yoo et al. (2000); Tong and Hawley (2009) and Kim and Kim (2004) who reported that brand loyalty had the major impact on overall brand equity. Yet, consistent with previous studies, brand loyalty, brand image and brand awareness influenced overall brand equity respectively. Therefore, in order for a company to leverage its overall brand equity, it is, absolutely, significant to maintain and retain its loyal customers through building strong long-term relationship with them. The goal is to hold good brand image to guarantee success over rivals; and to embrace strong associations to occupy distinct position in its consumers' minds, which eventually will turn into favorable attitude toward the company's brand.

Further, the effect of country of origin of brand (COB) on consumer-based brand equity dimensions (CBBE) was also investigated. The results indicated positive and significant relationships between $\mathrm{COB}$ and every dimension of CBBE. This result complies with Ulgado and Lee (1993) who, among other researchers, underscored the importance of COB for American students'. It is also consistent with Pappu et al. (2006) and Amonini et al.'s (1999), where the later authors, while researching Australian consumers', concluded that "the relative influence of the 'country of brand' and the 'country of manufacture' may be product or situation specific" (p. 20).

Consistent with previous studies conducted in developed countries namely USA and Australia r, the researcher has observed that the impact of COB was the largest in relation to perceived quality (e.g., Chao, 1998; Lim et al., 1994; Pappu et al., 2006). Such result implies that COB plays an integral role during the buying decision process where consumers develop their beliefs and perceptions for a brand because of its country of origin. Perceiving countries of origin of brands under study as countries that have high quality workmanship; innovative and very advanced in technology, is definitely influencing the consumers perceived quality of the brands originated from those countries.

Consistent with Yasin et al. (2007) results from Malaysia, Shahin et al. (2013), and Moradi and Zarei (2012) conclusions from Iran, the current research underscored significant positive relationship between COB and brand loyalty. The result reflects consumers trust in brands originated from industrial and more technologically advanced countries (e.g., USA, Canada and South Korea) and mirrors the extent to which consumers are perceiving brands originated from those countries as reliable and credible. Therefore, they are more preferred and frequently chosen during the purchasing decision process which in turn generate brand loyalty.

Significant positive relationship was found between COB and brand awareness. This result is because consumers nowadays became more knowledgeable and have access to so many information with just one click of a button. Therefore, there is a high probability that consumers are aware of the countries of origin of brands; this awareness interprets the positive relationship found. The study result confirms previous researches conclusions from Australia, Malaysia, Tunisia and Iran respectively (Pappu et al., 2006, 2007; Yasin et al., 2007; Hamzaoui-Essoussi \& Merunka, 2006; Moradi \& Zarei, 2012).

The current study emphasized significant positive association between $\mathrm{COB}$ and brand image. Hence, conforming Shahin et al. (2013) and Yasin et al. (2007) results from Iran and Malaysia correspondingly, consequently ensuring the fundamental role $\mathrm{COB}$ plays as a main source in brand image creation. Countries of origin of brands under investigation are perceived by consumers as countries with an image of advanced countries; prestigious; and creative in design. Accordingly, country of origin of brands under inquiries have been perceived as secondary association of the brands, therefore consumers will develop either favorable or unfavorable associations towards brands' image originated from those countries.

Besides the positive and significant impact confirmed between COB and consumer based brand equity (CBBE) dimensions, the study also found that $\mathrm{COB}$ has a positive and significant impact on overall brand equity.

Ahmed and d'Astous (1995) stressed the significance of COM as opposed to COB to consumers. However, consistent with Pappu et al. (2006), the current research found that CBBE dimensions of a brand manufactured in a country (i.e., China) other than the country of origin of the brand (i.e., USA; Canada and South Korea) to be positive yet significantly lower at all CBBE dimensions namely: perceived quality; brand loyalty; brand 
awareness and brand image. This result emphasized that Egyptian consumers' transferred their negative perceptions towards the "made in country", in our case China, to the respective mobile phones brands under investigation. Such perception is in conformance with Pappu et al. (2007) and Liu (2012) who reported that China has unfavourable macro and micro image ratings and concluded that its negative effect is transferrable to all other product categories that hold the "made in China" label. Further, the result confirms Haubl and Elord, (1999) and Hui and Zhou (2003) outcomes from Austria and USA respectively who reported that strong brands are highly affected and negatively evaluated when manufactured at a less favorable country than their country of brand (COB). Moreover, the study proved the existence of a positive and significant association between COM and overall brand equity.

In conclusion, it seems that the Egyptian consumers' evaluations of the relationship between COB and all CBBE dimensions conform to the outcomes from other developing countries specified by the World Bank in 2013. Those countries with a Gross National Income (GNI) with 11,905\$ and less (e.g., Malaysia, Iran and Tunisia), except for perceived quality where Egyptian consumers' taste is in light with both Australian consumers' and American students'. This outcome reflects a common characteristic among developing countries consumers' namely high level of brand loyalty due to higher levels of risk aversion arising from the attractive quality of products originated from developed countries coinciding with lack of sufficient information about existing alternatives. However, the Egyptian consumers' evaluations of the association between COM and CBBE are similar to those in the developed countries (e.g., USA, Austria, Australia). Such result indicates that consumers in both developed and developing countries perceive all consumer based brand equity dimensions significantly lower for products manufactured in countries with less favorable image than the country of origin.

One of the main objectives of the current research is to examine the relationship between COB, COM and overall brand equity OBE directly and indirectly via the mediating effect of consumer based brand equity dimensions (CBBE). The study results confirms the direct relation between COB, COM and overall brand equity. Yet, the findings do not grant support to the indirect relationship between COB - overall brand equity mediated by CBBE. Such result is inconsistent with Yasin et al. (2007) who indicated that brand distinctiveness fully mediates the relationship whereas brand loyalty and brand awareness perform as partial mediators. Meanwhile, the research result asserted the indirect relationship between COM - overall brand equity mediated by CBBE. The study revealed that all CBBE dimensions fully mediate the relationship.

Brand managers will have to take $\mathrm{COB}$ into consideration while marketing for their brands internationally. They also have to manage their CBBE dimensions effectively as long as they fully mediate the relation between COM and overall brand equity.

\section{Limitations and Future Research}

The current study only considers one product category. While this improves internal validity, it limits the external one. Future research would consider different product categories, for example convenience products and non-durable ones, given that Pappu et al. (2006) found that COB is product category specific. Further investigation is needed to examine whether the results can be generalized, as only three countries of origin of brands $(\mathrm{COB})$ and one country of manufacture $(\mathrm{COM})$ were included. Further research should take into account $\mathrm{COB}$ and $\mathrm{COM}$ effect from other developed and developing countries. Researchers could also investigate different sub-dimensions of $\mathrm{COO}$ for example Country of Assembly (COA) and Country of Design (COD). Other mediators such as culture could also be studied.

\section{References}

Aaker, D. A. (1991). Managing Brand Equity. New York, NY: the Free Press.

Aaker, D. A. (1992). Managing the Most Important Assets: Brand Equity. Strategy Leadership, 20(5), 56-58. http://dx.doi.org/10.1108/eb054384

Aaker, D. A. (1996). Measuring brand equity across products and markets. California Management Review, 38(3), 102-120. http://dx.doi.org/10.2307/41165845

Ahmed, S. A., \& d'Astous, A. (1995). Comparison of country-of-origin effects on household and organizational buyers' product perceptions. European Journal of Marketing, 29(3), 35-51. http://dx.doi.org/10.1108/03090569510145741

Ahmed, Z., Zbib, I., Sikander, A., \& Noujaim, R. (2012). Does Country of Brand Origin (COBO) for the Lebanese Consumers. EuroMed Journal of Business, $7(2), \quad$ 108-128. http://dx.doi.org/10.1108/14502191211245561 
Al-Sulaiti K. I., \& Baker M. J. (1998). Country of origin effects: a literature review. Marketing Intelligence and Planning, 16(3), 150-199. http://dx.doi.org/10.1108/02634509810217309

Ambler, T. (2003). Marketing and the Bottom Line: Creating the Measures of Success (2nd ed.). London: Financial Times/Prentice Hall.

Amonini, C., Keogh, J., \& Sweeney, J. C. (1999). The dual nature of country-of-origin effects - a study of Australian consumers' evaluations. Australasian Marketing Journal, 6(2), 13-27. http://dx.doi.org/10.1016/S1441-3582(98)70246-0

Apil, A. (2006). Foreign Product Perceptions and Country of Origin Analysis across Black Sea; Studies on Azerbaijan, Bulgaria, Georgia, Russia, and Turkey. IBSU International Refereed Multi-Disciplinary Scientific Journal, (IBSUSJ), 1(1), 22-38.

Bae, S. W. (1999). Effects of partitioned country of origin information on buyer assessment of bi-national products. Advances in Consumer Research, 26(3), 344-351.

Baldauf, A., Cravens, K., Diamantopoulos, A., \& Zeugner-Roth, K. P. (2009). The impact of product-country image and marketing effort on retailer-perceived brand equity: an empirical analysis. Journal of Retailing, 85(4), 437-452. http://dx.doi.org/10.1016/j.jretai.2009.04.004

Bamber, D., Phadke, S., \& Jyotishi, A. (2011). Product Knowledge, Ethnocentrism and Purchase Intention: COO Study in India. Amrita Vishwa Vidyapeetham, University- working paper 112/2011.

Baron, R. M., \& Kenny, D. A. (1986). The moderator mediator variable distinction in social psychological research: conceptual, strategic, and statistical considerations. Journal of Personality and Social Psychology, 51(6), 1173-1182. http://dx.doi.org/10.1037/0022-3514.51.6.1173

Batra, R.V., Alden, D., Steenkamp, J. B. E. M., \& Ramachander, S. (2000). Effects of brand local and non local origin on consumer attitudes in developing countries. Journal of Consumer Psychology, 9(2), 83-95. http://dx.doi.org/10.1207/S15327663JCP0902_3

Bilkey, W. J., \& Nes, E. (1982). Country of origin effects on product evaluation. Journal of International Business Studies, 8(1), 89-99. http://dx.doi.org/10.1057/palgrave.jibs.8490539

Boo, S., Busser, J., \& Baloglu, S. (2009). A model of customer-based brand equity and its application to multiple destinations. Tourism Management, 30(2), 219-231. http://dx.doi.org/10.1016/j.tourman.2008.06.003

Buil, I., Martínez, E., \& Chernatony, L. (2013). The influence of brand equity on consumer responses. Journal of Consumer Marketing, 30(1), 62-74. http://dx.doi.org/10.1108/07363761311290849

Chang, H. H., \& Liu, Y. M. (2009). The impact of brand equity on brand preference and purchase intentions in the service industries. The Service Industries Journal, 29(12), 1687-1706. http://dx.doi.org/10.1080/02642060902793557

Chao, P. (1993). Partitioning country of origin effects: consumer evaluations of a hybrid product. Journal of International Business Studies, 24(2), 291-306. http://dx.doi.org/10.1057/palgrave.jibs.8490851

Chao, P. (1998). Impact of country-of-origin dimensions on product quality and design quality perceptions. Journal of Business Research, 42(1), 1-6. http://dx.doi.org/10.1016/S0148-2963(97)00129-X

Chao, P. (2001). The Moderating Effects of Country of Assembly, Country of Parts, and Country of Design on Hybrid Product Evaluation. Journal of Advertising, 30(4), 67-81. http://dx.doi.org/10.1080/00913367.2001.10673652

Chao, P., Wuhrer, G., \& Werani, T. (2005). Celebrity and foreign brand names as moderators of country-of-origin effects. International Journal of Advertising, the Quarterly Review of Marketing Communications, 24(2), 173-184.

Chen, C., \& Tseng, W. (2010). Exploring Customer-based Airline Brand Equity: Evidence from Taiwan. Transportation Journal, 49(1), 24-34.

Chen, C., Chen, P., \& Huang, C. (2012). Brands and Consumer Behavior. Social Behavior and Personality, 40(1), 105-114. http://dx.doi.org/10.2224/sbp.2012.40.1.105

Chen, Y., \& Su, Y. (2012). Do Country-of-Manufacture and Country-of-Design Matter to Industrial Brand Equity? Journal of Business and Industrial Marketing, 27(1), 57-68. http://dx.doi.org/10.1108/08858621211188966 
Chowdhury, H. K. (2009). An examination of effects of partitioned country of origin on consumer product quality perceptions. International Journal of Consumer Studies, 33(4), 496-502. http://dx.doi.org/10.1111/j.1470-6431.2009.00783.x

Christodoulides, G., \& de Chernatony, L. (2010). Consumer-based brand equity conceptualisation and measurement. International Journal of Market Research, 52(1), 43-66. http://dx.doi.org/10.2501/S1470785310201053

Farquhar, P.H. (1989). Managing brand equity. Marketing Research, September, 24-33.

Fetscherin, M., \& Toncar, M. (2010). The Effect of the Country of Brand and the Country of Manufacturing of Automobiles: An Experimental Study of Consumers' Brand Personality Perception. International Marketing Review, 27(2), 164-178. http://dx.doi.org/10.1108/02651331021037494

Ha, H. Y., Swinder, J., \& Siva, M. (2010). Development of brand equity: evaluation of four alternative models. The Service Industries Journal, 30(6), 911-928. http://dx.doi.org/10.1080/02642060802320253

Hamzaoui-Essoussi, L., \& Merunka, D. (2006). The impact of country of design and country of manufacture on consumer perceptions of bi-national products' quality: an empirical model based on the concept of fit. Journal of Consumer Marketing, 23(3), 145-155. http://dx.doi.org/10.1108/07363760610663303

Hamzaoui-Essoussi, L., Merunka, D., \& Bartikowski, B. (2011). Brand origin and country of manufacture influences on brand equity and the moderating role of brand typicality. Journal of Business Research, 64(9), 973-978. http://dx.doi.org/10.1108/07363760610663303

Han, C. M., \& Terpstra, V. (1988). Country of origin effects for uni-national and bi-national products. Journal of International Business Studies, 19(2), 235-255. http://dx.doi.org/10.1108/07363760610663303

Haubl, G., \& Elrod, T. (1999). The Impact of Congruity between Brand Name and Country of Production on Consumers' Product Quality Judgments. International Journal of Research in Marketing, 16, 199-215. http://dx.doi.org/10.1016/S0167-8116(99)00011-7

Hui, M., \& Zhou, L. (2003). Country of Manufacture Effects for Known Brands. European Journal of Marketing, 37(1/2), 133-153. http://dx.doi.org/10.1108/03090560310458664

Ishaq, M., Hussain, N., Asim, A., \& Cheema, L. (2014). Brand Equity in the Pakistani Hotel Industry. Sao Paulo, 54(3), 284-295. http://dx.doi.org/10.1590/S0034-759020140304

Iyer, E. D., \& Kalita, J. K. (1997). The Impact of Country-of-Origin and Country-of-Manufacture Cues on Consumer Perceptions of Quality and Value. Journal of Global Marketing, 11(1), 7-28. http://dx.doi.org/10.1300/J042v11n01_02

Johansson, J. K., \& Nebenzahl, I. D. (1986). Multinational Production: Effect on Brand Value. Journal of International Business Studies, 17(3), 101-126. http://dx.doi.org/10.1057/palgrave.jibs.8490861

Keller, K. L. (1993). Conceptualizing, Measuring, and Managing Customer-Based Brand Equity. Journal of Marketing, 57(1), 1-22. http://dx.doi.org/10.2307/1252054

Keller, K. L. (2003). Brand Synthesis: The Multidimensionality of Brand Knowledge. Journal of Consumer Research, 29(4), 595-600. http://dx.doi.org/10.1086/346254

Keller, K. L. (2008). Strategic Brand Management: Building, Measuring and Managing Brand Equity (3rd ed.). Upper Saddle River, NJ: Pearson prentice-Hall.

Keller, K. L. (2010). Brand equity management in a multichannel, multimedia retail environment. Journal of Interactive Marketing, 24(2), 58-70. http://dx.doi.org/10.1016/j.intmar.2010.03.001

Keller, K. L. (2013). Strategic Brand Management: Building, Measuring, and Managing Brand Equity (4th ed.). Boston, MA: Pearson.

Khan, M., \& Mahmood, Z. (2012). Impact of Brand Loyalty Factors on Brand Equity. International Journal of Academic Research, 4(1), 33-37.

Kim, W. G., \& Kim, H. (2004). Measuring customer-based restaurant brand equity: Investigating the relationship between brand equity and firms' performance. Cornell Hotel and Restaurant Administration Quarterly, 45(2), 115-131. http://dx.doi.org/10.1177/0010880404264507

Lamelas, M. (2011). Conceptualizing and Measuring the Influence of Corporate Image on Country of Origin Image: the Case of Spain. Unpublished Ph.D. Thesis, Brunel Business School, Brunel University. 
Lassar, W., Mittal, B., \& Sharma, A. (1995). Measuring customer-based brand equity. Journal of Consumer Marketing, 12(4), 11-19. http://dx.doi.org/10.1108/07363769510095270

Leclerc, F., Schmitt, B. H., \& Dube', L. (1994). Foreign branding and its effect on product perceptions and attitudes. Journal of Marketing Research, 31, 263-270. http://dx.doi.org/10.2307/3152198

Lee, H., \& Lee, C. (2011). Country of Origin and Brand Redeployment Impact after Brand Acquisition. Journal of Consumer Marketing, 28(6), 412-420. http://dx.doi.org/10.1108/07363761111165921

Lim, J., Darley, W. K., \& Summers, J. O. (1994). An assessment of country of origin effects under alternative presentation formats. Journal of Academy of Marketing Science, 22(3), 274-282. http://dx.doi.org/10.1177/0092070394223008

Liu, Y. (2012). Country of Origin and Customer Based Brand Equity: A Quantitative Study on Chinese cars Going Global. Unpublished Master Thesis, Department of Marketing, Aalto University School of Economics.

Moradi, H., \& Zarei, A. (2012). Creating Consumer Based Brand Equity for Young Iranian Consumers via Sub-Components Country of Origin Effects. Asia Pacific Journal of Marketing and Logistics, 24(3), 394-413. http://dx.doi.org/10.1108/13555851211237885

Mourad, M., Ennew, C., \& Kortam, W. (2011). Brand equity in higher education. Marketing Intelligence \& Planning, 29(4), 403-420. http://dx.doi.org/10.1108/02634501111138563

Murtiasih, S., Sucherly, S., \& Siringoringo, H. (2014). Impact of country of origin and word of mouth on brand equity. Marketing Intelligence \& Planning, 32(5), 616-629. http://dx.doi.org/10.1108/MIP-04-2013-0073

Nunnally, J., \& Bernstein, I. (1994). Psychometric Theory (3rd ed.). NY: McGraw-Hill.

Osgood, C., \& Tannenbaum, P. (1955). The Principle of Congruity in the Prediction of Attitude Change. Psychological Review, 62(1), 42-55. http://dx.doi.org/10.1037/h0048153

Pappu, R., Quester, P. G., \& Cooksey, R. W. (2005). Consumer-based brand equity: improving the measurement: empirical evidence. Journal of Product \& Brand Management, 14(3), 143-154. http://dx.doi.org/10.1108/10610420510601012

Pappu, R., Quester, P. G., \& Cooksey, R. W. (2006). Consumer-based brand equity and country-of-originrelationship: some empirical evidence. European Journal of marketing, 40(5/6), 696-717. http://dx.doi.org/10.1108/03090560610657903

Pappu, R., Quester, P. G., \& Cooksey, R. W. (2007). Country image and consumer-based brand equity: relationships and implications for international marketing. Journal of International Business Studies, 38, 726-745. http://dx.doi.org/10.1057/palgrave.jibs.8400293

Park, S. H. (2009). The antecedent and consequences of brand image: Based on Keller's customer-based brand equity. Unpublished Doctor of Philosophy Thesis, The Ohio State University.

Peterson, R., \& Jolibert, A. (1995). A Meta-Analysis of Country-Of-Origin Effects. Journal of International Business Studies, 26(4), 883-900. http://dx.doi.org/10.1057/palgrave.jibs.8490824

Petra Zeugner-Roth, K., Diamantopoulos, A., \& Montesinos, M. (2008). Home Country Image, Country Brand Equity and Consumers' Product Preferences: An Empirical Study. Management International Review, 48(5), 577-602. http://dx.doi.org/10.1007/s11575-008-0031-y

Pinar, M., Girard, T., \& Eser, Z. (2012). Consumer-based brand equity in banking industry. International Journal of Bank Marketing, 30(5), 359-375. http://dx.doi.org/10.1108/02652321211247417

Pinar, M., Trapp, P., Girard, T., \& Boyt, T. (2014). University brand equity: an empirical investigation of its dimensions. International Journal of Educational Management, 28(6), 616-634. http://dx.doi.org/10.1108/IJEM-04-2013-0051

Pisharodi, R. M., \& Parameswaran, R. (1992). Confirmatory factor analysis of a country-of-origin scale: initial results. Advances in Consumer Research, 19, 706-714.

Prendergast, G., Tsang, A., \& Chan, C. (2010). The Interactive Influence of Country of Origin of Brand and Product Involvement on Purchase Intention. Journal of Consumer Marketing, 27(2), 180-188. http://dx.doi.org/10.1108/07363761011027277

Rackchamroon, P., \& Chaimanat, P. (2011). Influences of Country of Origin on Thai Consumers' Buying Decision Toward Beer Purchasing. Unpublished Master Thesis, Malaradalen University, Sweeden. 
Saeed, R., Khurshid, N., Safdar, M., Ahmad, W., Lodhi, R., \& Ahmad, W. (2013). Country-of-Origin (COO) Effect on Pakistani Consumers' Evaluation of French Cosmetic Products. Journal of Basic and Applied Scientific Research, 3(6), 988-1000.

Samli, A. C., \& Fevrier, M. (2008). Achieving and managing global brand equity: a critical analysis. Journal of Global Marketing, 21(3), 207-215. http://dx.doi.org/10.1080/08911760802152041

Shahin, A., Kazemi, A., \& Mahyari, H. (2013). How Consumer's Perception of Country of Origin affects Brand Equity: A Case Study in Iran. Journal of Basic and Applied Scientific Research, 3(2), 1203-1210.

Smutkupt, P., Krairit, D., \& Khang, D. (2012). Mobile marketing and consumer perceptions of brand equity. Asia Pacific Journal of Marketing and Logistics, 24(4), 539-560. http://dx.doi.org/10.1108/13555851211259016

Srinivasan, V., Park, C. S., \& Chang, D. R. (2005). An Approach to the Measurement, Analysis, and Prediction of Brand Equity and Its Sources. Management Science, 51(9), 1433-1448. http://dx.doi.org/10.1287/mnsc.1050.0405

Swaminathan, V., Stilley, K. M., \& Ahluwalia, R. (2009). When brand personality matters: the moderating role of attachment styles. Journal of Consumer Research, 35(6), 985-1002. http://dx.doi.org/10.1086/593948

Tong, X., \& Hawley, J. M. (2009). Measuring customer-based brand equity: Empirical evidence from the sportswear market in China. Journal of Product \& Brand Management, 18(4), 262-271. http://dx.doi.org/10.1108/10610420910972783

Ulgado, F., \& Lee, M. (1993). Consumer Evaluations of Bi-National Products in the Global Market. Journal of International Marketing, 1(3), 5-22.

Valette-Florence, P., Guizani, H., \& Merunka, D. (2011). The impact of brand personality and sale promotions on brand equity. Journal of Business Research, 64(1), 24-28. http://dx.doi.org/10.1016/j.jbusres.2009.09.015

Yasin, N., Noor, M., \& Mohamed, O. (2007). Does Image of Country-of-Origin Matter to Brand Equity? Journal of Product and Brand Management, 16(1), 38-48. http://dx.doi.org/10.1108/10610420710731142

Yoo, B., \& Donthu, N. (2002). Testing Cross Cultural Invariance of the Brand Equity Creation Process. Journal of Product and Brand Management, 11(6), 380-398. http://dx.doi.org/10.1108/10610420710731142

Yoo, B., Donthu, N., \& Lee, S. (2000). An Examination of Selected Marketing Mix Elements and Brand Equity. Journal of the Academy of Marketing Science, 28(2), 195-211. http://dx.doi.org/10.1177/0092070300282002

Zeithaml, V. A. (1988). Consumer Perceptions of Price, Quality, and Value: A Means-End Model and Synthesis of Evidence. Journal of Marketing, 52(3), 2-22. http://dx.doi.org/10.2307/1251446

Zeugner-Roth, K. P., Diamantopoulos, A., \& Montesinos, M. A. (2008). Home country image, country brand equity and consumers' product preferences: an empirical study. Management International Review, 48(5), 577-602. http://dx.doi.org/10.1007/s11575-008-0031-y

\section{Copyrights}

Copyright for this article is retained by the author(s), with first publication rights granted to the journal.

This is an open-access article distributed under the terms and conditions of the Creative Commons Attribution license (http://creativecommons.org/licenses/by/3.0/). 